significance should not be attached to the value of the $\mathrm{Zr} / \mathrm{Hf}$ ratio without further analyses.

This work has been supported in part by the US Atomic Energy Commission, the US National Aeronautics and Space Administration and the University of Kentucky Research Foundation. Specimen S-5211 was supplied by Dr Carleton B. Moore, Arizona State University, and specimen S-5207 (US National Museum specimen number USNM 3510) by Dr R. S. Clarke, jun., US National Museum. We also thank Dr Clarke for pertinent suggestions, and the Air Force NEC Nuclear Reactor Facility in Dayton, Ohio, for their cooperation.

J. W. Morgan

T. V. REBAGAY

D. L. Showalter

R. A. NADKARNI

D. E. GILLUM

D. M. MoKown

W. D. EHMANN

Department of Chemistry,

University of Kentucky,

Lexington, Kentucky 40506.

Received September 29, 1969.

${ }^{2}$ King, jun., E. A., Schonfeld, F., Richardson, K. A., and Eldridge, J. S., Science, 163, 928 (1969). 2 Vogt, J. R., Ehmann, W. D., and McEllistrem, M. T., Int. J. Appl. Radiat.
Isotopes, 16, 573 (1965).

${ }^{3}$ Ehmann, W. D., and McKown, D. M., Anat. Lett., 2, 49 (1969).

4 Ehmann, W. D., and McKown, D. M. Modern Trends in Activation Anatysis, NBS Spec. Pub. $312,1,308$ (US Dept. of Commerce, 1969).

${ }^{5}$ Rebagay, T. V., thesis, Univ. Kentucky (1969).

- Baedecker, P. A., and Ehmann, W. D., Geochim. Cosmochim. A.cta, 29, 329 (1965).

"Mason, B., Space Sci. Rev., 1, 621 (1963).

8 Wiik, H. B., Geochim. Cosmochim. Acta, 9, 279 (1956).

'Yan Schmus, W. R., and Wood, J. A., Geochim. Cosmochim. Acta, 31, 747 (1967).

${ }^{10}$ Amiruddin, A., and Ehmann, W. D., Geochim. Cosmochim. Acta, 26, 1011 (1962) ${ }^{11}$ Crocket, J. H., Keays, R. R., and Hsieh, S., Geochim. Cosmochim. Acta, 31,
1615 (1987).

\section{Middle East Rift Zones}

EARIIER this year we proposed a model for the evolution of the Middle East rift zones ${ }^{1}$. In this it was shown that the motion of the three major crustal plates, Nubia, Somalia and Arabia, was such that it could be described as rotational about a single pole, the differing rates of rotation producing the intervening rift zones. In a criticism of this account, Roberts ${ }^{2}$ has proposed a modified model involving a three-plate, three-pole solution. This more general method should theoretically describe the motions of the plates more precisely than the one-pole, three-plate approximation which we adopted. The procedurcs and assumptions used by Roberts to determine the pole positions are, however, open to question, and hence his conclusions are of doubtful validity.

We originally stated that we consider that the motions of the three plates may be described as approximating to rotation about the Libyan polo of Le Pichon and Hertzler ${ }^{3}$. One of the reasons for the approximation is that there is some evidence that the plates suffer internal deformation for, although Morgan ${ }^{4}$ has indicated that deformation within the plates is insignificant on a macrocontinental scale, the plates considered here are smaller and such deformation may thus become significant. This important complicating factor is ignored by Roberts in his attempt to provide a more precise analysis.

The validity of the pole determined by Roberts for the relative motions of the Nubian and Somali plates is also open to question. This pole was determined indirectly from the poles for the relative motions of the Nubian/ Arabian plates and Somali/Arabian plates and is therefore dependent on the accuracy of these two pole positions. The pole for the separation along the Red Sea is particularly poorly defined, because it was determined by Roberts from azimuths of lines joining conjugate points on either side of the Red Sea, from the rates of opening of the Red Sea at $16^{\circ} \mathrm{N}$, and the rate of shear along the Dead Sea fault zone. Even if one accepts the validity of the conjugate point procedure for deformed plates, one surely cannot ignore the possibility of considerable amounts of deformation along the line of the Gulf of Suez. Thus a study of the deformation along the Dead Sea fault zone looks only at the relative motions of the Sinai and Arabian plates and not at the relative motions of Nubia and Arabia. The Sinai peninsula and the adjacent regions west of the Jordan valley are almost certainly a discrete, although small, continental plate separated by the Gulf of Suez from the Nubian plate. It follows therefore that the position of the pole describing the relative motions of the Nubian and Somali plates must be in error.

It should be noted that, although we consider the Ethiopian Rift as a zone of sinistral shear, we agree there has been an additional amount of crustal separation along this line. An assessment of the relativo significance of shear and tensional separation may have to await the results of measurements of the actual movements of the plates, and this project has been planned by the Smithsonian Institution. The results of other geophysical investigations in progress will also bear on this problem.

Because of the inherent uncertainties in applying an exact geometrical model to geological realities we feel the treatment of the Middle East region as a three-plate, one-pole problem in plate tectonics to be a reasonable approximation. This admittedly simplified model emphasizes the important north-easterly drift of the three separated crustal plates which has dominated the tectonics of this part of the Earth's crust for at least the last 20 m.y.

Department of Earth Sciences,

I. L. Gibsox

University of Leeds.

I. G. GASS

Department of Earth Sciences,

The Open University,

Walton, nr Bletchley.

Received September 10, 1969.

1 Gass, I. G., and Gibson, I. L., Nature, 221, 926 (1969).

"Roberts, D. G. Nature, 223,55 (1969).

${ }^{3}$ Le Pichon, X., and Hertzler, J. R., J. Geophys, Res., 73, 6, 2101 (1968).

${ }^{4}$ Morgan, W. J., J. Geophys. Res., 73, 1959 (1968).

\section{Dredged Basalt from the Reykjanes Ridge, North Atlantic}

The Reykjanes Ridge in the North Atlantic Ocean has been ${ }^{1}$ an important example in derivations of the theory of sea-floor spreading. A detailed dredging programme by the $R / V$ Trident (September 1967) with camera and gravity core stations covered a profile across the crest of the Reykjanes Ridge (at latitude $60^{\circ} \mathrm{N}$, Fig. 1) to look for direct information on the mechanism of spreading and to test one suggested explanation ${ }^{1}$. Many data were already available $^{2-4}$. Continuous depth, total magnetic intensity and seismic profiling measurements along this traverse correlated the new data with the old (magnetic, gravity and seismic). There was also a secondary, incomplete profile at latitude $61^{\circ} 25^{\prime} \mathrm{N}, 150 \mathrm{~km}$ north, as well as heat flow measurements by $\mathbf{K}$. Horai and M. Chessman of the Massachusetts Institute of Technology. 